Article

\title{
A Real-Time PCR Method for the Authentication of Common Cuttlefish (Sepia officinalis) in Food Products
}

\author{
Amaya Velasco *, Graciela Ramilo-Fernández ${ }^{\mathbb{D}}$ and Carmen G. Sotelo $\mathbb{D}$ \\ Instituto de Investigaciones Marinas (IIM-CSIC), Eduardo Cabello 6, 36208 Vigo (Pontevedra), Spain; \\ graciela@iim.csic.es (G.R.-F.); carmen@iim.csic.es (C.G.S.) \\ * Correspondence: amayavelasco@iim.csic.es; Tel.: +34-986-23-19-30
}

Received: 6 February 2020; Accepted: 28 February 2020; Published: 4 March 2020

\begin{abstract}
Cephalopods are very relevant food resources. The common cuttlefish (Sepia officinalis) is highly appreciated by consumers and there is a lack of rapid methods for its authentication in food products. We introduce a new minor groove binding (MGB) TaqMan real-time PCR (Polymerase Chain Reaction) method for the authentication of S. officinalis in food products to amplify a 122 base pairs (bp) fragment of the mitochondrial COI (Cytochrome Oxidase I) region. Reference and commercial samples of $S$. officinalis showed a threshold cycle $(\mathrm{Ct})$ mean of 14.40 , while the rest of the species examined did not amplify, or showed a significantly different $\mathrm{Ct}(p<0.001)$. The calculated efficiency of the system was $101 \%$, and the minimum DNA quantity detected was $10^{-4} \mathrm{ng}$. No cross-reactivity was detected with any other species, thus, the designed method differentiates S. officinalis from other species of the genus Sepia and other cephalopod species and works for fresh, frozen, grilled, cooked and canned samples of Sepia spp. The method has proved to be reliable and rapid, and it may prove to be a useful tool for the control of fraud in cuttlefish products.
\end{abstract}

Keywords: Sepia; common cuttlefish; Sepia officinalis; real-time PCR (Polymerase Chain Reaction); species identification; food authentication; COI (Cytochrome Oxidase I)

\section{Introduction}

Cephalopods are a very diverse group of mollusks and include 28 families and more than 600 species, many of which are commercially important. As a sign of their relevance, captures of cephalopods in 2017 reached 3,772,565 t, with an estimated value of almost 8000 million dollars [1].

The common cuttlefish (S. officinalis) is highly appreciated by consumers around the world, and it is traded with different presentations particularly in Japan, the Republic of Korea, Italy and Spain. In the last decade, the world catches attributed to this species have registered numbers between 20,000 and 30,000 tons every year [2]. It is the species of cuttlefish with the highest commercial value.

European regulations regarding the labeling of fishery products [3,4] establish that these products must show the information about the species, with the commercial and/or scientific name depending on the type of product. Illicit substitution of one species for another may constitute economic fraud and/or misbranding violations. Furthermore, species substitution may cause potential food safety hazards to be overlooked by processors or end-users [5]. Species substitution is relatively frequent in seafood products [6], and particularly in products containing cephalopods, where several cases of species substitution have been reported $[7,8]$.

Species belonging to the genus Sepia can look very similar to a non-trained consumer, especially when they are processed for the market (e.g., peeled, canned), making the visual differentiation almost impossible and increasing the possibilities of fraud. Thus, the reported cases of mislabeling in products 
containing Sepia spp. have usually been substitutions between species belonging to the same genus $[9,10]$. These cases can be attributed to economic fraud (e.g., substitutions between species with different commercial value) or unintentional substitutions, which can be due to similar geographic distribution of species (e.g., S. officinalis/S. orbignyanya/S. elegans) and/or similar morphological characteristics (e.g., juveniles of S. officinalis/S. elegans) which can lead to misidentification at any level of the value chain (fisheries, processors and consumers). In order to control these substitutions, a variety of genetic methods have been published for the identification of several cephalopod species. The majority of these are labor-intensive and time-consuming, such as forensically informative nucleotide sequencing (FINS), barcoding [10-14] and RFLP [8,15]. Some rapid DNA-based methods have also been published for the authentication of some cephalopod species [7,16-18], but to date, there is not any rapid technique available for the genetic identification of $S$. officinalis.

This work presents a rapid and reliable method for the authentication of S. officinalis in different food matrices, including processed products. Therefore, it can be a useful tool for control authorities at different levels of the value chain.

\section{Materials and Methods}

\subsection{Sampling and DNA Extraction}

In this work, 14 samples of $S$. officinalis from different locations of Spanish and Portuguese waters were used as a reference. Also, 29 individuals from 20 other cephalopod species of 11 genera from the Instituto de Investigaciones Marinas (IIM-CSIC) own tissue collection were included for the specificity assay (Table 1). All reference individuals had a known origin and were identified visually prior to the FINS identification. Additionally, 16 commercial samples were collected from supermarkets and restaurants in Galicia region (Spain) for the application to commercial products (Table 2). All tissue samples were stored at $-20^{\circ} \mathrm{C}$ until analysis.

Table 1. Reference samples used in this study and threshold cycle $(\mathrm{Ct})$ results.

\begin{tabular}{|c|c|c|c|c|}
\hline Sample Code & Species & Common Name (FAO) & Geographic Origin & Ct Mean \pm SD \\
\hline SOFF2 & Sepia officinalis & Common cuttlefish & Atlantic, Northeast (FAO 27.9) Vigo & $12.98 \pm 0.32$ \\
\hline SOFF3 & Sepia officinalis & Common cuttlefish & Atlantic, Northeast (FAO 27.9) Cambados & $14.05 \pm 0.26$ \\
\hline SOFF4 & Sepia officinalis & Common cuttlefish & Atlantic, Northeast (FAO 27.9) Cambados & $14.80 \pm 0.04$ \\
\hline SOFF5 & Sepia officinalis & Common cuttlefish & Atlantic, Northeast (FAO 27.9) Cambados & $16.16 \pm 0.35$ \\
\hline SOFF6 & Sepia officinalis & Common cuttlefish & Atlantic, Northeast (FAO 27.9) Vigo & $13.57 \pm 0.70$ \\
\hline SOFF7 & Sepia officinalis & Common cuttlefish & Atlantic, Northeast (FAO 27.9) Vigo & $15.37 \pm 0.10$ \\
\hline SOFF8 & Sepia officinalis & Common cuttlefish & Atlantic, Northeast (FAO 27.9) Vigo & $13.51 \pm 0.07$ \\
\hline SOFF9 & Sepia officinalis & Common cuttlefish & Atlantic, Northeast (FAO 27) & $14.11 \pm 0.20$ \\
\hline SOFF10 & Sepia officinalis & Common cuttlefish & Atlantic, Northeast (FAO 27) & $15.65 \pm 0.21$ \\
\hline SOFF11 & Sepia officinalis & Common cuttlefish & Atlantic, Northeast (FAO 27) & $13.86 \pm 0.48$ \\
\hline SOFF12 & Sepia officinalis & Common cuttlefish & Atlantic, Northeast (FAO 27) & $13.25 \pm 0.39$ \\
\hline SOFF15 & Sepia officinalis & Common cuttlefish & Atlantic, Northeast (FAO 27.9) Algarve & $12.72 \pm 0.06$ \\
\hline SOFF16 & Sepia officinalis & Common cuttlefish & Atlantic, Northeast (FAO 27.9) Algarve & $12.59 \pm 0.19$ \\
\hline SOFF17 & Sepia officinalis & Common cuttlefish & Atlantic, Northeast (FAO 27.9) Algarve & $13.98 \pm 0.12$ \\
\hline SBER 2 & Sepia betheloti & African cuttlefish & Atlantic, Eastern Central (FAO 34) & $\geq 40$ \\
\hline SBER 3 & Sepia betheloti & African cuttlefish & Atlantic, Eastern Central (FAO 34) & $\geq 40$ \\
\hline SORB 4 & Sepia orbygniana & Pink cuttlefish & Atlantic, Northeast (FAO 27) & $\geq 40$ \\
\hline SORB 5 & Sepia orbygniana & Pink cuttlefish & Atlantic, Northeast (FAO 27) & $\geq 40$ \\
\hline SPHA 1 & Sepia pharaonis & Pharaon cuttlefish & Indian Ocean, Western (FAO 51) & $\geq 40$ \\
\hline LVUL 2 & Loligo vulgaris & European squid & Western Central Atlantic (FAO 31) & $27.00 \pm 0.16$ \\
\hline LVUL 1 & Loligo vulgaris & European squid & Atlantic, Northeast (FAO 27) & $26.03 \pm 0.28$ \\
\hline LVUL 5 & Loligo vulgaris & European squid & Atlantic, Northeast (FAO 27) & $29.15 \pm 0.14$ \\
\hline LVUL 3 & Loligo vulgaris & European squid & Western Central Atlantic (FAO 31) & $\geq 40$ \\
\hline LVUL 4 & Loligo vulgaris & European squid & Western Central Atlantic (FAO 31) & $\geq 40$ \\
\hline LVUL 6 & Loligo vulgaris & European squid & Western Central Atlantic (FAO 31) & $\geq 40$ \\
\hline LVUL 7 & Loligo vulgaris & European squid & Western Central Atlantic (FAO 31) & $\geq 40$ \\
\hline LVUL 8 & Loligo vulgaris & European squid & Western Central Atlantic (FAO 31) & $29.80 \pm 0.40$ \\
\hline LREY 1 & Loligo reynaudi & Cape Hope squid & Atlantic, Southeast (FAO 47) & $\geq 40$ \\
\hline IILL 2 & Illex illecebrosus & Northern Shortfin squid & Atlantic, Northwest (FAO 21) & $\geq 40$ \\
\hline TEBL 1 & Todaropsis eblanae & Lesser flying squid & Atlantic, Northeast (FAO 27) & $\geq 40$ \\
\hline TPAC 3 & Todarodes pacificus & Japanese flying squid & Pacific, Northwest (FAO 61) & $\geq 40$ \\
\hline ICOI 10 & Illex coindetii & Southern shortfin squid & Atlantic, Northeast (FAO 27) & $\geq 40$ \\
\hline LGAH 9 & Loligo gahi & Patagonian squid & Pacific, Southeast (FAO 87) & $\geq 40$ \\
\hline MHYA 8 & Martialia hyadesi & Sevenstar flying squid & Atlantic, Antarctic (FAO 48) & $\geq 40$ \\
\hline NSLO6 & Nototodarus sloanii & Wellington flying squid & Pacific, Southwest (FAO 81) & $\geq 40$ \\
\hline
\end{tabular}


Table 1. Cont.

\begin{tabular}{ccccc}
\hline Sample Code & Species & Common Name (FAO) & Geographic Origin & Ct Mean \pm SD \\
\hline TSAG 1 & Todarodes sagittatus & European flying squid & Atlantic, Northeast (FAO 27) & Atlantic, Northeast (FAO 27) \\
OVUL 142 & Octopus vulgaris & Common octopus & Atlo & Pacific, Western Central (FAO 71) \\
OCYA 3 & Octopus cyanea & Big blue octopus & Pacific, Western Central (FAO 71) & $\geq 40$ \\
OCYA 4 & Octopus cyanea & Big blue octopus & Pacific, Southeast (FAO 87) & $\geq 40$ \\
OMIM 1 & Octopus mimus & Changos octopus & Atlantic, Northeast (FAO 27) & $\geq 40$ \\
ECIR 143 & Eledone cirrhosa & Horned octopus & Pacific, Southeast (FAO 87) & $\geq 40$ \\
DGIG 1 & Dosidicus gigas & Jumbo squid & Indian Ocean, Western (FAO 51) & $\geq 40$ \\
AMEM 1 & Amphioctopus membranaceus & Webfoot octopus & (F0 & \\
\hline
\end{tabular}

FAO: Food and Agriculture Organization. SD: Standard Deviation.

Table 2. Commercial samples used for validation. The mislabeled samples are highlighted in red.

\begin{tabular}{|c|c|c|c|c|c|}
\hline $\begin{array}{l}\text { Sample } \\
\text { Code }\end{array}$ & $\begin{array}{c}\text { Type of } \\
\text { Processing }\end{array}$ & $\begin{array}{c}\text { Type of } \\
\text { Establishment }\end{array}$ & Species Declared & $\begin{array}{l}\text { Species Identified by } \\
\text { FINS }\end{array}$ & Ct Mean \pm SD \\
\hline S1 & Frozen & Supermarket & Sepia spp. & Sepia pharaonis & $29.77 \pm 0.62$ \\
\hline S2 & Frozen & Supermarket & Sepia spp. & Sepia pharaonis & $27.68 \pm 0.06$ \\
\hline S3 & Frozen & Supermarket & Sepia spp. & Sepia sp (not S. officinalis) & $\geq 40$ \\
\hline S4 & Frozen & Supermarket & "Sepia" & Sepia sp (not S. officinalis) & $31.85 \pm 0.26$ \\
\hline S5 & Canned & Supermarket & "Sepia" & Sepia officinalis & $16.91 \pm 0.47$ \\
\hline S6 & Frozen & Supermarket & Sepia spp. & Sepia sp (not S. officinalis) & $\geq 40$ \\
\hline S7 & Cooked & Supermarket & Sepia officinalis & Sepia officinalis & $17.88 \pm 0.94$ \\
\hline S8 & Canned & Supermarket & "Sepia" & Sepia officinalis & $15.41 \pm 0.03$ \\
\hline S10 & Grilled & Restaurant & "Choco" & Sepia officinalis & $13.70 \pm 0.06$ \\
\hline S11 & Frozen & Supermarket & Sepia aculeata & Sepia sp (not S. officinalis) & $\geq 40$ \\
\hline $\mathrm{S} 12$ & Frozen & Supermarket & Sepiella spp. & Sepiella inermis & $\geq 40$ \\
\hline S13 & Frozen & Supermarket & Sepia pharaonis & Sepia aculeata & $\geq 40$ \\
\hline S14 & Thawed & Supermarket & Sepia officinalis & Sepia officinalis & $14.03 \pm 0.28$ \\
\hline S15 & Grilled & Restaurant & "Sepia" & Sepia bertheloti & $26.08 \pm 0.11$ \\
\hline S16 & Thawed & Supermarket & Sepia officinalis & Sepia officinalis & $13.43 \pm 0.06$ \\
\hline S17 & Canned & Supermarket & "Sepia" & Sepia pharaonis & $23.62 \pm 0.23$ \\
\hline
\end{tabular}

FINS: Forensically Informative Nucleotide Sequencing.

A portion of $0.3 \mathrm{~g}$ of muscle tissue from each sample was digested at $56^{\circ} \mathrm{C}$ in a thermo shaker with $860 \mu \mathrm{L}$ of lysis buffer (1\% Sodium Dodecyl Sulfate (SDS), $150 \mathrm{mM} \mathrm{NaCl}, 2 \mathrm{mM}$ Ethylenediaminetetraacetic acid (EDTA) and $10 \mathrm{mM}$ Tris- $\mathrm{HCl}$ at $\mathrm{pH}$ 8), $100 \mu \mathrm{L}$ of guanidinium thiocyanate $5 \mathrm{M}$ and $40 \mu \mathrm{L}$ of proteinase $\mathrm{K}(20 \mathrm{mg} / \mathrm{mL})$. After $3 \mathrm{~h}, 40 \mu \mathrm{L}$ of extra proteinase $\mathrm{K}$ was added and left overnight. DNA was isolated with the Wizard DNA Clean-up System kit (Promega, Madison, WI, USA) following the manufacturer's protocol. Double-stranded DNA obtained was quantified with Qubit dsDNA BR Assay Kit (Life Technologies, Carlsbad, CA, USA) and Qubit 3.0 fluorometer (Invitrogen, Carlsbad, CA, USA). Purified DNA was stored at $-20{ }^{\circ} \mathrm{C}$ until further analysis.

\subsection{FINS Identification of Samples}

Reference and commercial samples were authenticated by FINS (forensically informative nucleotide sequencing) in order to test the reliability of the method developed. PCR reactions were carried out in a Verity 96 wells Thermal cycler (Applied Biosystems, Foster City, CA, USA) with Illustra PuReTaq Ready-To-Go PCR Beads (GE Healthcare, Chicago, IL, USA), $1 \mu \mathrm{L}$ of each primer $(10 \mu \mathrm{M})$ and $100 \mathrm{ng}$ of template DNA in a final volume of $25 \mu \mathrm{L}$. Primers designed by Folmer [19] LCO1490-5' GGTCAACAAATCATAAAGATATTGG3' and HCO2198-5'TAAACTTCAGGGTGACCAA AAAATCA3' were used to amplify a 750 base pairs (bp) fragment of the mitochondrial COI region, with the following thermal protocol: a preheating step of $3 \mathrm{~min}$ at $95^{\circ} \mathrm{C}$, followed by 35 cycles of $1 \mathrm{~min}$ at $95^{\circ} \mathrm{C}, 1 \mathrm{~min}$ at $40{ }^{\circ} \mathrm{C}$ and $1.5 \mathrm{~min}$ at $72{ }^{\circ} \mathrm{C}$, with a final extension step at $72{ }^{\circ} \mathrm{C}$ for $7 \mathrm{~min}$. When amplification of COI fragment failed, the 16SVAR primers described by Chapela [11] 16SVAR-F5'CAAATTACGCTGTTATCCCTATGG3' and 16SVAR-R- 5'GACGAGAAGACCCTAATGAGCTTT3' were used to amplify a $210 \mathrm{bp}$ fragment of the mitochondrial $16 \mathrm{~S} \mathrm{rDNA}$, with the thermal protocol as follows: a preheating step of $3 \mathrm{~min}$ at $95^{\circ} \mathrm{C}$, followed by 35 cycles of $40 \mathrm{~s}$ at $94{ }^{\circ} \mathrm{C}, 40 \mathrm{~s}$ at $50{ }^{\circ} \mathrm{C}$ and $40 \mathrm{~s}$ 
at $72{ }^{\circ} \mathrm{C}$, with a final extension step at $72{ }^{\circ} \mathrm{C}$ for $7 \mathrm{~min}$. Negative and positive controls were included in all PCR sets.

Primers designed in this study for the minor groove binding (MGB)-TaqMan assay were also used for FINS identification in 3 cases of processed commercial samples of Sepia spp. (cooked and canned), where both COI and $16 \mathrm{~S}$ sets of primers failed to amplify, with the following thermal protocol: a preheating step of $3 \mathrm{~min}$ at $95^{\circ} \mathrm{C}$, followed by 35 cycles of $40 \mathrm{~s}$ at $95^{\circ} \mathrm{C}, 40 \mathrm{~s}$ at $40^{\circ} \mathrm{C}$ and $40 \mathrm{~s}$ at $72{ }^{\circ} \mathrm{C}$ with a final extension step at $72{ }^{\circ} \mathrm{C}$ for $7 \mathrm{~min}$. PCR amplicons were visualized on a $2 \%$ agarose gel, using UV transillumination (BioRad, Hercules, CA, USA).

PCR products were purified with Illustra ExoProStar (GE Healthcare, Chicago, IL, USA) and sequencing reactions were performed with BigDye Terminator 1.1 (Applied Biosystems, Foster City, CA, USA), following the manufacturer's instructions. The automatic sequencing was carried out in an ABI PRISM 3130 (Applied Biosystems, Foster City, CA, USA). After automatic sequencing, F and R files were edited with Chromas and aligned with Bioedit [20] to obtain the complete sequence of the fragment. Bioedit software was also used to align the resulting sequence with reference ones from the NCBI and the IIM-CSIC sequence database, which consists of more than 2000 sequences from fish and mollusks specimens that have been collected during 30 years; most of these specimens were morphologically identified and also genetically authenticated. This alignment was imported with MEGA [21] for phylogenetic analysis. The phylogenetic model used for constructing the neighbor-joining tree was Tamura-Nei, with 1000 bootstrap replicates. The results were also authenticated with BLAST [22]. The multiple alignments and the BLAST tool were also used to check the quality and coverage of the resulting sequences.

The COI sequences obtained for reference and commercial samples of this study were uploaded to Genbank [23] (accession numbers: MN977128 to MN977135, MN977138, MN977143, MN977144, MN977146, MN977147, MN977149, MN977152, MN977154 to MN977156, MN977158, MN977159, MN977161 to MN977171, MN977173 to MN977177, MN977179 to MN977191).

\subsection{RT-PCR Design}

In order to find a suitable fragment to design a short and specific system, a large number of nuclear and mitochondrial cephalopod sequences from public and IIM-CSIC databases were aligned and analyzed. A fragment of the COI region was suitable for the design of an MGB-Taq-Man Primers and Probe set, complying with the requirements of showing low intraspecific variability and high interspecific variability and allowing the amplification of a short fragment (122 bp, primers included). The sequences of primers ( $F$ and $R$ ) and Probe $(P)$ are the following (see Figure 1):

SOFI_F: 5'CTTCTCCTTACATTTAGCWGGRGTCT3'

SOFI_R: FAM-5'TACCGAYCAAGCAAATAAAGGTAGG3'-MGB

SOFI_P: 5' AGCGATTAACTTCATCA3'

\subsection{Real-Time PCR Conditions and Data Treatment}

Concentrations of 50, 300 and $900 \mathrm{nM}$ of each primer and 25, 50, 75, 100, 125, 150, 175, 200 and $225 \mathrm{nM}$ of the probe were tested in order to select the optimal reaction conditions. The combination that gave the lowest threshold cycle $(\mathrm{Ct})$ value and the highest final fluorescence was selected for the subsequent assays. The selected concentrations were 300 nM of SOFI_F primer, 900 nM of SOFI_R primer and $150 \mathrm{nM}$ of SOFI_P probe.

Thus, each $20 \mu \mathrm{L}$ reaction contained $10 \mu \mathrm{L}$ of TaqMan Fast Universal Master Mix (2X), No AmpErase UNG (Applied Biosystems, Foster City, CA, USA), $1 \mu \mathrm{L}$ of Primer SOFI_F $(6 \mu \mathrm{M}), 1 \mu \mathrm{L}$ of Primer SOFI_R $(18 \mu \mathrm{M}), 1 \mu \mathrm{L}$ of Probe SOFI_P $(3 \mu \mathrm{M})$ and $100 \mathrm{ng}$ of template DNA. Reactions were amplified in a 7500 fast real-time PCR System (Applied Biosystems, Foster City, CA, USA), with the fast ramp speed protocol: $95^{\circ} \mathrm{C}$ for $20 \mathrm{~s}$, followed by 40 cycles of $95^{\circ} \mathrm{C}$ for $3 \mathrm{~s}$ and $60^{\circ} \mathrm{C}$ for $30 \mathrm{~s}$. Samples were analyzed in triplicate, and $\mathrm{Ct}$ mean and standard deviation of each individual were registered. 


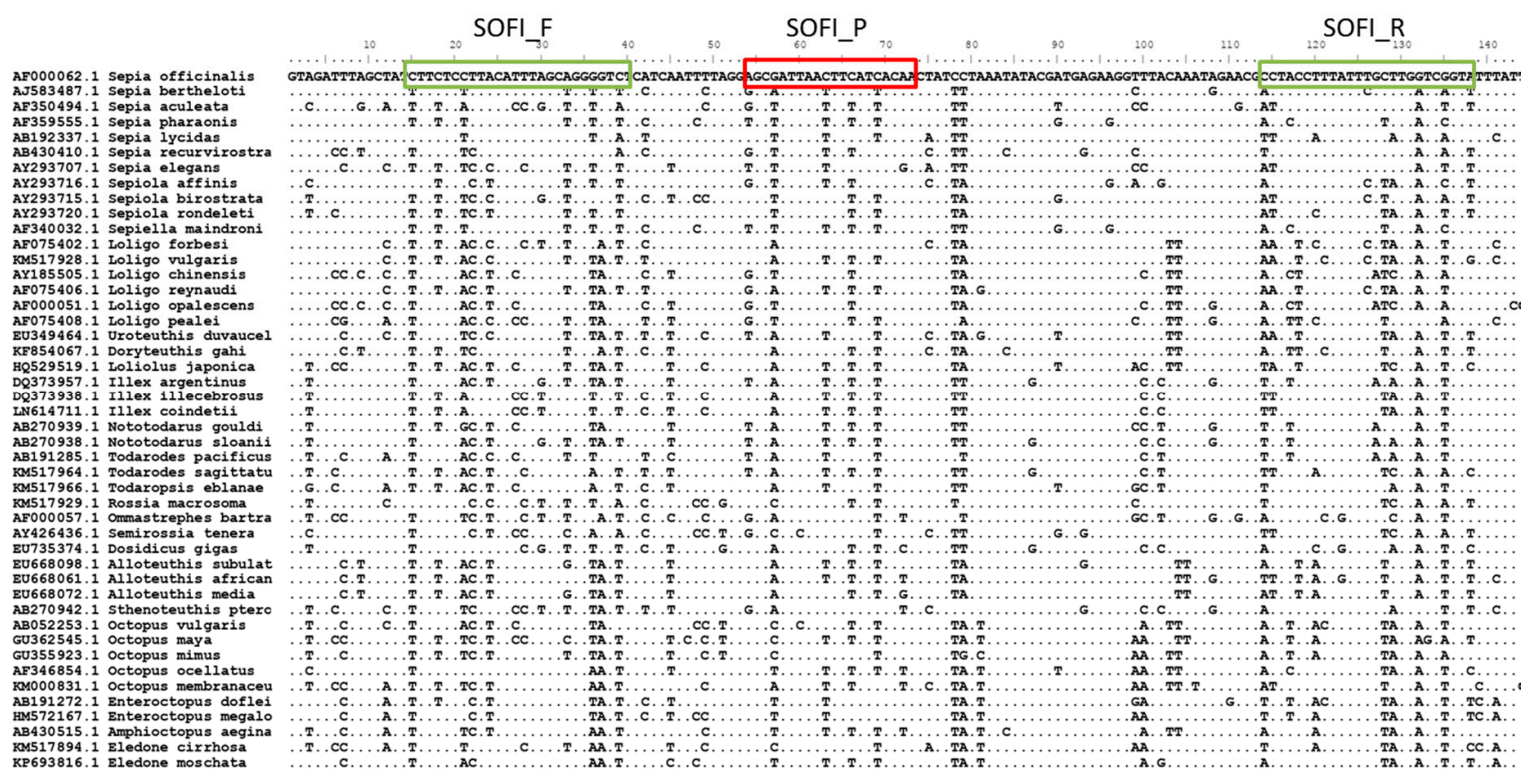

Figure 1. Multiple sequence alignment of the mitochondrial COI (Cytochrome Oxidase I) fragment, showing the position of the primers and probe designed.

\section{Results}

\subsection{Efficiency and Detection Limit}

Different quantities of template DNA of $S$. officinalis, from $10^{-5} \mathrm{ng}$ to $100 \mathrm{ng}$ were used for the efficiency assay. Over this range of dilutions, the response was linear with a slope of -3.13 , an $R^{2}$ of 0.999 and an efficiency of $101 \%$, following the equation: $E=10^{-1 / b}-1$ [24]. The acceptable efficiency values range from $90 \%$ to $110 \%$, therefore, $101 \%$ can be considered ideally optimal. The minimum quantity of DNA detected was $10^{-4} \mathrm{ng}$. The automatic threshold generated in this assay was 0.02 , the value used in the subsequent analyses.

\subsection{Inclusivity and Specificity}

A total of 14 samples of $S$. officinalis from different locations and dates of capture were tested (Table 1), obtaining Ct data between 12.59 and 16.16, with a Ct mean of 14.04 (Figure 2A).
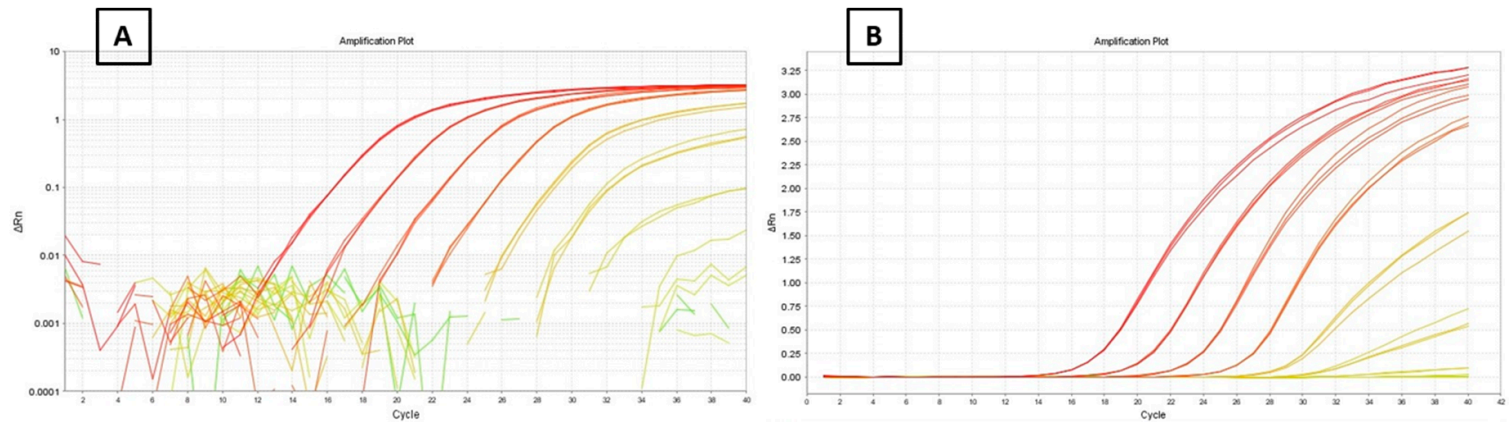

Figure 2. Amplification plots of the 10X dilution series of Sepia officinalis DNA (A): logarithmic,

(B): linear.

In the other 19 species tested (Table 1), none of them presented any fluorescence signal with the exception of one specimen of Loligo vulgaris, which showed a late amplification signal (Figure 3B). In view of these results, another specificity assay was carried out with seven additional individuals of L. vulgaris, obtaining a $\mathrm{Ct}$ mean of 34.0, a result that is significantly different from the $\mathrm{Ct}$ of $\mathrm{S}$. officinalis when a mean comparison test (one way ANOVA) was run $(p<0.001)$. 

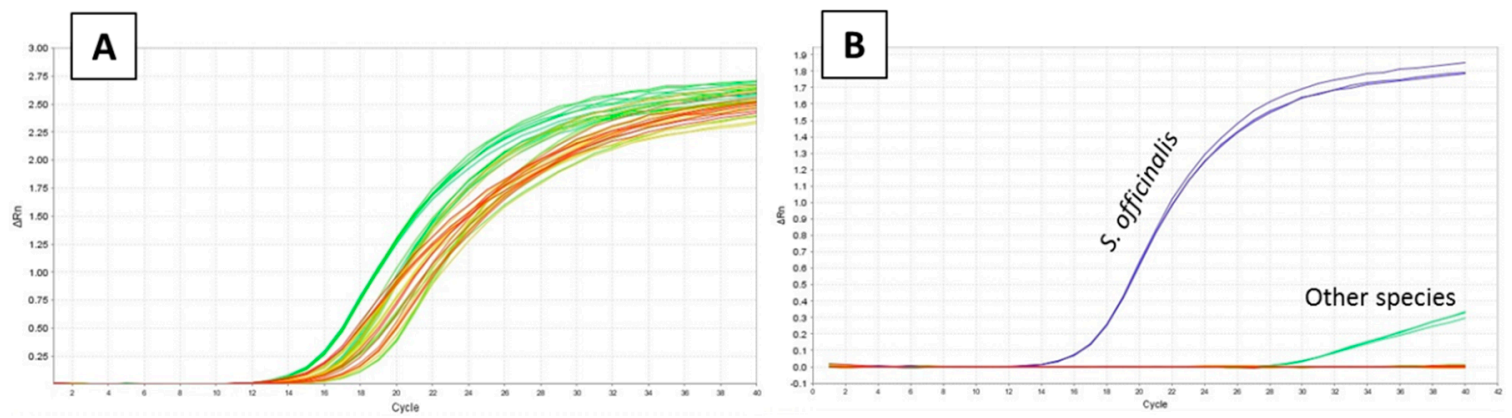

Figure 3. (A) Inclusivity test: amplification pattern of reference samples of Sepia officinalis. (B) Specificity test: amplification pattern of reference samples of Sepia officinalis and the rest of the species tested.

\subsection{Application to Commercial Products}

According to the Spanish regulations for the labeling of fresh, frozen and refrigerated fishery products, the commercial name "Sepia", "Choco" or "Jibia" is only accepted for products containing S. officinalis, while the commercial name "Sepias" can be used for all species of the genus Sepia [25]. In the same way, the commercial name "Jibia" or "Sepia" can be only applied to canned products containing the species S. officinalis [26]. Therefore, the system was also tested with 16 commercial samples labeled as "Sepia", "Choco" or "Sepias", from supermarkets and restaurants of Galicia (Spain), with different degrees of processing such as thawed, frozen, grilled, cooked and canned.

Following the above-mentioned criteria, the FINS identification results of this study revealed four cases of mislabeling regarding species (Table 2), all being substitutions between different species of the genus Sepia, constituting a mislabeling rate of $25 \%$. The substitute species found were Sepia pharaonis, Sepia aculeata, Sepia bertheloti and a non-identified species. In four cases, it was not possible to reach the species level with the FINS identification, due to the lack of reference sequences in public databases, but authors could determine that these samples did not belong to $S$. officinalis species by analyzing the results of the neighbor-joining tree and the BLAST tool. The MGB TaqMan real-time PCR system worked in fresh and processed samples of $S$. officinalis, and the method was able to differentiate between products containing S. officinalis (Ct mean 15.23) and products containing other species of the Sepiidae family (Ct mean 33.82), with statistical significance $(p<0.001)$. The type of processing did not affect the $\mathrm{Ct}$ values, and a good differentiation was obtained both in fresh and frozen products as well as in highly processed samples, such as canned.

The $\mathrm{Ct}$ results obtained for both reference and commercial samples containing S. officinalis ranged from 12.59 to 17.88 , with a $\mathrm{Ct}$ mean of 14.40 , while the rest of species remained undetected or showed late amplification, with $\mathrm{Ct}$ values of 23.62 and higher and a mean $\mathrm{Ct}$ of 33.40 and this $\mathrm{Ct}$ mean resulted significantly different from the $\mathrm{Ct}$ of samples containing $\mathrm{S}$. officinalis $(p<0.001)$.

\section{Discussion}

Results confirm TaqMan real-time PCR technique as a powerful tool for species authentication, due to its characteristics of specificity, increased with Minor Groove Binding technology (MGB probes) [27], and its sensitivity, allowing the detection of very low quantities of target DNA. Real-time PCR also allows the detection and quantification of target DNA in one step, eliminating post-PCR steps and saving labor time. The method described in this work includes these characteristics of specificity, sensitivity and fastness, since the real-time PCR analysis takes around $40 \mathrm{~min}$, which means that, depending on the tissue digestion protocol, the complete analysis from the tissue sample can be carried out in 3-4 h. This feature and the reduced equipment needed, opens the possibility of the optimization of the method for analyses on-site at the different levels of the value chain, including the point of sale. The cost of the analysis (less than 5 euros per sample) is also much lower than sequencing-based methods, which makes it affordable for low-resources control units. 
S. officinalis is marketed under several types of processing, including those that eliminate the characteristics for visual identification, such as peeling, cutting, cooking and canning. This makes these products vulnerable to species substitution, intentional or not. Results also show that the design of the primer set allows the amplification and authentication of the species even in samples where processing may lead to DNA degradation and/or fragmentation, such as canning. The lack of rapid methods for this task makes the control of this market laborious and costly, and this technique emerges as the only available alternative at the moment.

The sampling at supermarkets has also revealed that Spanish legislation of the commercial names in canned products needs to be updated since it has not been reviewed since 1986. Taking into account the current legislation, canned products are not obliged to show the scientific name on the labels, i.e., commercial names such as "Sepia" can be found, which correspond to several species. The authors consider that this system is no longer suitable for the current market, where the amount of cephalopod species in the market has greatly increased while different species may achieve significant differences in market price.

The Ct values obtained in this study for the target species are at the same level or lower than other recent works using the TaqMan real-time PCR technique for species identification [28,29]. The significant differences found between the data corresponding to $S$. officinalis and the other species prove that $\mathrm{Ct}$ values can be used to determine whether a sample contains $S$. officinalis or another cephalopod species. Results also prove the high specificity of the system, which works for the differentiation of S. officinalis from the other species of the genus Sepia with commercial importance, demonstrating the utility of the method in food control, since the reported cases of mislabeling in the family Sepiidae show substitutions between species belonging to the same genus, as shown in previous publications $[9,10]$ and confirmed in this study. Although the system has not been tested with all the species of the genus Sepia, this study included those with relevance to the market. Nonetheless, further analysis could be carried out to confirm the specificity of the method with other species of the genus Sepia which might have some commercial relevance in certain countries. The level of mislabeling found in this work (25\%) is slightly lower than those found in the aforementioned articles, but still in the range of significant mislabeling. However, the different sampling procedures do not allow an adequate comparison, therefore, authors cannot affirm that there has been a decrease in the mislabeling rates. Nevertheless, these results highlight the need for an effective tool for the control of this type of product.

\section{Conclusions}

As a conclusion, this work presents a rapid, non-expensive and reliable method, able to differentiate S. officinalis from other species of the genus Sepia and other cephalopod species in food samples with different levels of processing, making it useful for food control authorities in the whole food value chain.

This study also found a moderate level of mislabeling in Sepia products, which highlights the need for more efficient control of the authenticity of this type of product.

Author Contributions: Conceptualization, A.V. and C.G.S.; methodology, A.V. and G.R.-F.; software, A.V.; supervision, C.G.S.; writing-original draft, A.V.; writing-review and editing, G.R.F. and C.G.S. All authors have read and agreed to the published version of the manuscript.

Funding: This study is part of the SEATRACES project (www.seatraces.eu), funded by the EU Interreg Atlantic Area Programme (project number EAPA_87/2016).

Acknowledgments: We acknowledge the Border Control Post of Vigo (BCP Vigo), Rogério Mendes, Patricia Ramos and Marta Pérez for providing tissue samples.

Conflicts of Interest: The authors declare no conflict of interest. 


\section{References}

1. FAO. Fishery and Aquaculture Statistics; 2017/FAO annuaire; FAO: Rome, Italy, 2019.

2. Fisheries and Aquaculture Software. FishStatJ-Software for Fishery and Aquaculture Statistical Time Series. In FAO Fisheries and Aquaculture Department; FAO: Rome, Italy, 2016; Updated 21 July 2016. Available online: http://www.fao.org/fishery/Rome (accessed on 6 November 2019).

3. Regulation (EU) No 1169/2011 of the European Parliament and of the Council of 25 October 2011 on the provision of food information to consumers, amending Regulations (EC) No 1924/2006 and (EC) No 1925/2006 of the European Parliament and of the Council, and repealing Commission Directive 87/250/EEC, Council Directive 90/496/EEC, Commission Directive 1999/10/EC, Directive 2000/13/EC of the European Parliament and of the Council, Commission Directives 2002/67/EC and 2008/5/EC and Commission Regulation (EC) No 608/2004. Available online: https://eur-lex.europa.eu/LexUriServ/LexUriServ.do?uri=OJ:L:2011:304:0018: 0063:EN:PDF (accessed on 25 October 2011).

4. Regulation (EU) No 1379/2013 of the European Parliament and of the Council of 11 December 2013 on the common organisation of the markets in fishery and aquaculture products, amending Council Regulations (EC) No 1184/2006 and (EC) No 1224/2009 and repealing Council Regulation (EC) No 104/2000. Available online: https://eur-lex.europa.eu/LexUriServ/LexUriServ.do?uri=OJ:L:2013:354:0001:0021:EN:PDF (accessed on 11 December 2013).

5. FDA, Food and Drug Administration; U.S. Department of Health and Human Services. Fish and Fishery Products: Hazards and Controls Guidance, 4th ed.; Chapter 3; IFAS-University of Florida: Gainesville, FL, USA, 2019.

6. Warner, K.; Mustain, P.; Lowell, B.; Geren, S.; Talmage, S. Deceptive Dishes: Seafood Swaps Found Worldwide; Oceana Reports; Oceana: New York, NY, USA, 2016; Available online: www.oceana.org (accessed on 12 December 2019).

7. Espiñeira, M.; Vieites, J.M. Rapid method for controlling the correct labeling of products containing common octopus (Octopus vulgaris) and main substitute species (Eledone cirrhosa and Dosidicus gigas) by fast real-time PCR. Food Chem. 2012, 135, 2439-2444. [CrossRef] [PubMed]

8. Santaclara, F.J.; Espiñeira, M.; Vieites, J.M. Genetic identification of squids (families Ommastrephidae and Loliginidae) by PCR-RFLP and FINS methodologies. J. Agric. Food Chem. 2007, 55, 9913-9920. [CrossRef] [PubMed]

9. Guardone, L.; Tinacci, L.; Costanzo, F.; Azzarelli, D.; D’Amico, P.; Tasselli, G.; Magni, A.; Guidi, A.; Nucera, D.; Armani, A. DNA barcoding as a tool for detecting mislabeling of fishery products imported from third countries: An official survey conducted at the Border Inspection Post of Livorno-Pisa (Italy). Food Control 2017, 80, 204-216. [CrossRef]

10. Espiñeira, M.; Vieites, J.M.; Santaclara, F.J. Species authentication of octopus, cuttlefish, bobtail and bottle squids (families Octopodidae, Sepiidae and Sepiolidae) by FINS methodology in seafoods. Food Chem. 2010, 121, 527-532. [CrossRef]

11. Chapela, M.J.; Sotelo, C.G.; Calo-Mata, P.; Pérez-Martín, R.I.; Rehbein, H.; Hold, G.L.; Quinteiro, J.; Rey-Méndez, M.; Rosa, C.; Santos, A.T. Identification of cephalopod species (Ommastrephidae and Loliginidae) in seafood products by Forensically Informative Nucleotide Sequencing (FINS). J. Food Sci. 2002, 67, 1672-1676. [CrossRef]

12. Chapela, M.J.; Sotelo, C.G.; Pérez-Martín, R.I. Molecular identification of cephalopod species by FINS and PCR-RFLP of a cytochrome b gene fragment. Eur. Food Res. Technol. 2003, 217, 524-529. [CrossRef]

13. Sin, Y.W.; Yau, C.; Chu, K.H. Morphological and genetic differentiation of two loliginid squids, Uroteuthis (Photololigo) chinensis and Uroteuthis (Photololigo) edulis (Cephalopoda: Loliginidae), in Asia. J. Exp. Mar. Biol. Ecol. 2009, 369, 22-30. [CrossRef]

14. Undheim, E.A.; Norman, J.A.; Thoen, H.H.; Fry, B.G. Genetic identification of Southern Ocean octopod samples using mtCOI. C. R. Biol. 2010, 333, 395-404. [CrossRef] [PubMed]

15. Colombo, F.; Cerioli, M.; Colombo, M.M.; Marchisio, E.; Malandra, R.; Renon, P. A simple polymerase chain reaction-restriction fragment length polymorphism (PCR-RFLP) method for the differentiation of cephalopod mollusc families Loliginidae from Ommastrephidae, to avoid substitutions in fishery field. Food Control 2002, 13, 185-190. [CrossRef] 
16. Herrero, B.; Lago, F.C.; Vieites, J.M.; Espiñeira, M. Rapid method for controlling the correct labeling of products containing European squid (Loligo vulgaris) by fast real-time PCR. Eur. Food Res. Technol. 2012, 234, 77-85. [CrossRef]

17. Ye, J.; Feng, J.; Liu, S.; Zhang, Y.; Jiang, X.; Dai, Z. Identification of four squid species by quantitative real-time polymerase chain reaction. Mol. Cell. Probes 2016, 30, 22-29. [CrossRef] [PubMed]

18. Ye, J.; Feng, J.; Dai, Z.; Meng, L.; Zhang, Y.; Jiang, X. Application of Loop-Mediated Isothermal Amplification (LAMP) for Rapid Detection of Jumbo Flying Squid Dosidicus gigas (D'Orbigny, 1835). Food Anal. Methods 2017, 10, 1452-1459. [CrossRef]

19. Folmer, O.; Black, M.; Hoeh, W.; Lutz, R.; Vrijenhoek, R. DNA primers for amplification of mitochondrial cytochrome c oxidase subunit I from diverse metazoan invertebrates. Mol. Mar. Biol. Biotechnol. 1994, 3, 294-299. [PubMed]

20. Hall, T.A. BioEdit: A user-friendly biological sequence alignment editor and analysis program for Windows 95/98/NT. Nuceicl. Acids Symp. Ser. 1999, 41, 95-98.

21. Kumar, S.; Dudley, J.; Nei, M.; Tamura, K. MEGA: A biologist-centric software for evolutionary analysis of DNA and protein sequences. Brief. Bioinform. 2008, 9, 299-306. [CrossRef] [PubMed]

22. Altschul, S.F.; Madden, T.L.; Schaffer, A.A.; Zhang, J.; Zhang, Z.; Millar, W.; Lipman, D.J. Gapped BLAST and PSIBLAST: A new generation of protein database search programs. Nucleic Acids Res. 1997, 25, 3389-3402. [CrossRef] [PubMed]

23. Clark, K.; Karsch-Mizrachi, I.; Lipman, D.J.; Ostell, J.; Sayers, E.W. GenBank. Nucleic Acids Res. 2016, 44, D67-D72. [CrossRef] [PubMed]

24. Dorak, M.T. Real-Time PCR; Taylor \& Francis Group: New York, NY, USA, 2006.

25. Resolución de 26 de enero de 2018, de la Secretaría General del Mar, por la que se establece y se publica el listado de denominaciones comerciales de especies pesqueras y de acuicultura admitidas en España; BOE-A-2018-2884; Boletín oficial del Estado núm. 53, de 1 de marzo de 2018; Ministerio de Medio Ambiente, Medio Rural y Marino: Madrid, Spain, 2018; pp. 25487-25513.

26. ORDEN de 17 de enero de 1986 sobre norma reguladora del comercio exterior de las conservas de cefalópodos; Boletín oficial del Estado Núm. 30; Ministerio de Economía y Hacienda: Madrid, Spain, 1986; pp. 4682-4684.

27. Kutyavin, I.V.; Afonina, I.A.; Mills, A.; Gorn, V.V.; Lukhtanov, E.A.; Belousov, E.S.; Singer, M.J.; Walburger, D.K.; Lokhov, S.G.; Gall, A.A.; et al. 3'-minor groove binder-DNA probes increase sequence specificity at PCR extension temperatures. Nucleic Acids Res. 2000, 28, 655-661. [CrossRef] [PubMed]

28. Luekasemsuk, T.; Panvisavas, N.; Chaturongakul, S. TaqMan qPCR for detection and quantification of mitochondrial DNA from toxic pufferfish species. Toxicon 2015, 102, 43-47. [CrossRef] [PubMed]

29. Fernandes, T.J.R.; Costa, J.; Oliveira, M.B.P.P.; Mafra, I. Exploiting $16 \mathrm{~S}$ rRNA gene for the detection and quantification of fish as a potential allergenic food: A comparison of two real-time PCR approaches. Food Chem. 2018, 245, 1034-1041. [CrossRef]

(C) 2020 by the authors. Licensee MDPI, Basel, Switzerland. This article is an open access article distributed under the terms and conditions of the Creative Commons Attribution (CC BY) license (http://creativecommons.org/licenses/by/4.0/). 